University at Buffalo School of Law

Digital Commons @ University at Buffalo School of Law

7-1-1991

\title{
Women of Color and Health: Issues of Gender, Community, and Power
}

Judy Scales-Trent

University at Buffalo School of Law

Follow this and additional works at: https://digitalcommons.law.buffalo.edu/journal_articles

Part of the Gender and Sexuality Commons, Law Commons, and the Race and Ethnicity Commons

\section{Recommended Citation}

Judy Scales-Trent, Women of Color and Health: Issues of Gender, Community, and Power, 43 Stan. L. Rev. 1357 (1991).

Available at: https://digitalcommons.law.buffalo.edu/journal_articles/829

\section{C) ${ }_{\text {COPYRIGHT }}^{\text {N }}$}

This Article is brought to you for free and open access by the Faculty Scholarship at Digital Commons @ University at Buffalo School of Law. It has been accepted for inclusion in Journal Articles by an authorized administrator of Digital Commons @ University at Buffalo School of Law. For more information, please contact lawscholar@buffalo.edu. 


\title{
Women of Color and Health: Issues of Gender, Community, and Power
}

\author{
Judy Scales-Trent*
}

\section{INTRODUCTION}

America is the land of modern medical technology, skilled surgeons, miracle medicines, and state-of-the-art medical facilities. It is also the land where access to even adequate health care is not available to all. In this article, I will look at the health issues that affect women of color, a group of Americans disfavored by virtue of their sex and racial or ethnic background. ${ }^{1}$ What are their health issues? And how are these issues connected with other concerns of the communities of people of color around the country? By placing them in this context, I hope to make visible the issues of women who are themselves barely visible in this country. I will then address the issue of the limited research on health issues of women of color and describe changes in the field of medical research which may signal a positive change in direction.

Finally, I will use the context of health to address the question of what we mean by a "women of color issue." Does such an issue truly exist? If so, how can it be identified? And is there any way to separate issues which affect women of color from those which affect all poor women? Coming to grips with this conceptual problem will not only clarify the nature of the health issues faced by women of color, but should also enrich our future discussions on other aspects of their lives.

* Professor of Law, State University of New York at Buffalo.

An earlier version of this paper was presented at the Third National Conference on Women of Color and the Law, Stanford Law School, October 6, 1990.

1. The term "women of color" embraces a disparate group of roughly 24 million women. According to the 1980 Census, in 1980 there were approximately 14 million black women in the United States. There were 7.3 million Latinas, of whom 4.3 million were of Mexican descent. Just over 1 million were Puerto Rican, nearly 600,000 were women of Central and South American origin and 400,000 were Cuban. Nearly 2 million women of Asian and Pacific Island ethnicity lived in this country. Japanese-American, Chinese-American, and Filipino groups each accounted for approximately 400,000 of that total. Koreans and Asian-Indians accounted for 200,000 women each; Vietnamese-American women numbered just over 100,000; Hawailian women were nearly 90,000 in number; and Guamanian and Samoan women accounted for nearly 20,000 each. The smallest group of women of color were American Indian, Eskimo and Aleuts, who together account for less than 800,000 in this country. 1 U.S. DeP'T OF Commerce, BuReau of Census, 1980 Census of PopuLATION, ch. C, pt. 1, 1-12, 1-13 (1983) (Tables 74 and 75); U.S. DEP'T OF LABOR, WOMENS BUREAU, TIME OF CHANGE: 1983 HANDBOOK ON WOMEN WORKERS 29 (1983) (number of women of Central and South American origin). The term "American Indian" encompasses more than 300 tribes which speak more than 200 languages. Eileen M. O'Brien, The Demise of Native American Education, BLACK Issues IN Higher EdUCATION, Mar. 15, 1990, at 15, 16. 


\section{Health Issues in Context}

Before returning to law school as a faculty member, I practiced employment discrimination law for ten years. As a result, when $I$ look at health issues, I look at them through the lens of work. And because I recently stayed at a hotel in California, I think about the health issues of women of color from the perspective of the Latina women who clean the hotel room where I stayed. This is an appropriate place to start because so many women of color have jobs like this-marginal jobs which provide no training, little security, no possibility of advancement; ${ }^{2}$ jobs where the wages are depressed because of the color and sex of the jobholder. ${ }^{3}$ Women of color are the maids, the cleaners. ${ }^{4}$ They are the health care workers at the bottom rung of the health care industry; ${ }^{5}$ the lowest paid clericals; ${ }^{6}$ the women hidden in the sweatshops and the fields. ${ }^{7}$

So, when I think of the Latina woman who cleaned my hotel room, I have many questions about the relationship between her work and her health. I wonder, for example, what kind of health benefits, if any, she gets from her employer. ${ }^{8}$ Do they cover preventive medical care, or does her health situation have to become a crisis before she can afford to seek medical care? Do they cover abortions? If not, where will the money for an abortion come from? From her food money? As Rosalind Petchesky has noted: " 'Plenty of rent checks have gone unpaid, and plenty of food bills have been snipped in half, in order to pay for abortions-with disastrous results to poor women's health and that of their families." "9

Suppose she does find the money for an abortion. Suppose she has to have another kind of operation. Or suppose she needs to rest because of the flu, a kidney infection, or a battered body. Will her employer save her job for her while she recuperates? Or will she have to forego the operation, not get the rest her body needs, because she can't risk losing her job? Further, if

2. See U.S. COMM'N ON CIVIL RIGHTS, UNEMPLOYMENT AND UNDEREMPLOYMENT OF BlaCks, Hispanics, aNd WOMEN 7-9, 20-21 (1982).

3. Nat'l Comm. on Pay Equity, Pay Equity: An Issue of Race, Ethnicity and Sex 99-100 (1987) [hereinafter PAY EQUITY].

4. The three occupational categories with the largest percentage of black women are private household workers, cooks, and housekeepers. Id. at 28 (Table 5a). "Housekeeper" is also the second largest occupational category for Latinas. Id. at 29 (Table 5b).

5. In the health industry, $30 \%$ of all ancillary, auxiliary, or service workers are female; $84 \%$ of these women are black. They work as nurses' aides, cooks, laundresses, and housekeepers. Laurie Nsiah-Jefferson, Reproductive Laws, Women of Color, and Low-Income Women, 11 WOMEN's RTS. L. REP. 15, 28 \& n.87 (1989); see also Julianne Malveaux \& Susan Englander, Race and Class in Nursing Occupations, SAGE, Spring 1986, at 41.

6. PAY EQUITY, supra note 3, at 174 ("While women of color and White women work in the same occupational category, women of color are further segregated within these categories."); PHYLLIS A. WALlACE, BlaCK WOMEN IN THE LABOR ForCE 25 (1980).

7. Nsiah-Jefferson, supra note 5 , at 28.

8. Blacks, Puerto Ricans, and Mexican-Americans are at least twice as likely as whites not to have health insurance. Ruth E. Zambrana, A Research Agenda on Issues Affecting Poor and Minority Women: A Model for Understanding Their Health Needs, 12 WOMEN \& HEALTH 137, 149 (1988).

9. Rosalind Petchesky, Abortion and Woman's Choice: The State, Sexuality aNd Reproductive Freedom 161 (1985) (quoting Bebe Moore Campbell, Abortion: The New Facts of Life, EsSENCE, Sept. 1981, at 87, 126). 
she must care for herself and thereby loses her job, and with it money for food and housing, how will that outcome affect her health?

I imagine that her wages are very low. Does this job pay her enough so that she can afford nutritious food? Or does it pay her so little that she skimps on food for herself to provide good food for her children? Does she earn enough to pay the bus fare to the doctor's office? I also wonder if the job pays her just enough to make her ineligible for any Medicaid benefits she might otherwise receive. ${ }^{10}$

Even worse, does the job itself make her sick? For many women of color, it does. Many Puerto Rican and Asian-American women work in the textile industry under sweatshop conditions. They spend grueling hours in poorly ventilated rooms, working with toxic chemicals. ${ }^{11}$ Others work in the health care industry where they are harmed by their proximity to anesthetic gases and X-rays. They harm themselves by performing heavy lifting. ${ }^{12}$ Authorities estimate that 75 percent of migrant farmworkers are Mexican-American and another 20 percent are black. Many of these, of course, are women-women who work and live in an environment filled with pesticides. ${ }^{13}$

I wonder, therefore, what health hazards face the Latina maids at the hotel. Do they have to work with toxic cleaning compounds? Are they forced to do heavy lifting for which they don't have the strength? Also, although all women in the workplace are vulnerable to sexual harassment, studies have shown that those women who are most vulnerable-by reason of race, age, marital status, or job status-are harassed the most and most severely. Women of color are in that group. ${ }^{14}$ Health problems follow: headaches, stomach pains, ulcers. ${ }^{15}$ Are our Latina hotel maids demeaned and attacked in this way? Does this harassment make them sick?

The advantage of looking at health and employment together is that it reminds us that health issues are only one thread in a very complicated

10. Nsiah-Jefferson, supra note 5, at 28-29. Each state sets an income ceiling for Medicaid eligibility, although the federal government sets both a "floor" and a "ceiling" for those requirements. Nat'l Health law Program, an advocate's Guide to the Medically Needy Program 11-13 (1985).

11. Nsiah-Jefferson, supra note 5, at 28.

12. Id.

13. Id. These are a few of the indirect, subtle ways in which the work women of color perform in our society has negative consequences for their health. There are also more direct and more brutal work-health connections. Researchers have determined that the leading cause of death for women in the workplace is homicide. Homicide is Top Cause of Death From On-Job Injury for Women, N.Y. Times, Aug. 18, 1990, § 1, at 8 . The workplace murder rate for black women is nearly double that of white women. Id. It is also important to note that women of color join the military in disproportionate numbers. In 1989, black women alone comprised fully one-third of all active duty enlisted women. Brenda L. Moore, African-American Women in the United States Military, 17 ARMED FORCES \& SOC'Y 363, 363 (1991).

14. James E. Gruber \& Lars Bjorn, Blue-Collar Blues: The Sexual Harassment of Women Autoworkers, 9 WORK \& OCCUPATIONS 271, 284-86 (1982).

15. See, e.g., Cline v. General Elec. Capital Auto Lease, Inc., 757 F. Supp. 923, 928 (N.D. Ill. 1991) (sexual harassment caused Temporal Mandibular Joint Dysfunction, facial neuralgia; damaged facial nerves subsequently caused abscessed teeth); Zabkowicz v. West Bend Co., $589 \mathrm{~F}$. Supp. 780, 783 (E.D. Wis. 1984) (sexual harassment caused diarrhea, vomiting, nausea, cramping). 
fabric of oppression. Everything we bring home from work affects our health. ${ }^{16}$ Poor health is connected to dangerous jobs and to marginal jobs with low wages. Moreover, the kind of job we get is related to the kind of education we get. For many children of color, that education will not be very good. Even in so-called integrated schools, second-generation discrimination funnels disproportionate numbers of these children into lower academic groups. ${ }^{17}$ With a decent education, some of our children might be able to stretch beyond the reach of racism. Without it, they will not.

Our ability or inability to give our children this kind of education is very much controlled by housing, that is, by where women of color are allowed to live. Studies have shown that households headed by women of color are at a particular disadvantage in the rental market. They face discrimination based on race and on the presence of children, as well as discrimination based on their source of income if they are on public assistance. ${ }^{18}$ If we are segregated into ghettos through the discrimination of landlords, mortgage money lenders, house sellers, and the municipal housing authorities, then it is easier for those in power to limit our children's education. This form of segregation and control is common. ${ }^{19}$ Bad housing and bad schooling are connected.

Also, segregated housing often means dangerous housing. What health problems are related to living in a neighborhood where drive-by shootings are common, ${ }^{20}$ or where a woman and her children must sleep on the floor to avoid stray bullets? ${ }^{21}$ Further, if we are segregated into confined areas, how much easier it is to control the political response after dumping toxic

16. Ysaye M. Barnwell described this in a song she composed for Sweet Honey in the Rock:

We bring more than a paycheck

to our loved ones and families ...

We bring asbestosis, silicosis,

brown lung, black lung disease,

radiation hits the children

before they really been conceived ....

We All . . Everyone of Us (Flying Fish Music, BMI 1983); see also Zambrana, supra note 8, at 151 ("Black women have a $39 \%$ greater chance of sustaining job-related disease and serious work-related injuries than nonminorities.").

17. See Kenneth J. Meier, Joseph Stewart, Jr. \& Robert E. England, Race, Class and Education: The Politics of SeCond-Generation Discrimination 4-6 (1989).

18. Cushing N. Dolbeare \& Anne J. Stone, Women and Affordable Housing, in THE AMERICAN Woman 1990-1991: A STATUS Report 94, 104 (S. Rix ed. 1990). There is no federal law which prohibits discrimination against applicants for rental housing on the basis of source of income. Id. at 105 .

19. See generally U.S. COMm'N ON Civil Rights, A Sheltered CRISIS: The STATE OF Fair Housing in THE Eighties 104-32 (1983); Diane E. Gold, Housing Market Discrimination: CAUSES AND EFFECTS OF SLUM Formation (1980); see also United States v. Yonkers Bd. of Educ., 624 F. Supp. 1276, 1545 (S.D.N.Y. 1985) (city's segregative housing practices directly implicated in racial segregation of public schools).

20. See, e.g., David C. Rudd, Bloody Weekend Leaves 4 Dead, Dozens Hurt, Chicago Trib., Aug. 13,1990, § 2, at 1 (eight drive-by shootings in the city in one weekend).

21. See, e.g., Jesse Katz, Officers' Folksy Tactics Pay Off in Gang Domain, L.A. Times, Nov. 5, 1990 , at B6 (residents sleep on floors in their homes as protection from random shootings). 
waste in our communities. ${ }^{22}$ A Mohawk midwife recently noticed an increased number of miscarriages and problems with newborn babies among those she delivered on the St. Regis reservation. A state study found that because industry had been dumping chemicals into the St. Lawrence River where Indians fished, there was a high level of contamination on the reservation and high levels of PCBs in the breast milk of Mohawk mothers. ${ }^{23}$

Our poor health is connected to the kind of work we are allowed to do. Our inability to find good work is related to bad education, which is in turn related to segregated housing. Segregated housing, often dangerous housing, in turn affects our health, which, in turn, affects our ability to work. It is all of a piece. Pull any one of these strands and our lives unravel. We will not get well until our communities get well.

It is not surprising, therefore, that women of color are not in good health. ${ }^{24}$ AIDS is killing many of us. The statistics tell a grim story. More than 70 percent of all women with AIDS are black or Latina. ${ }^{25}$ In New York City, black and Puerto Rican women constitute 84 percent of all women with AIDS. ${ }^{26}$ In New York and New Jersey, it is the leading killer of young black women. ${ }^{27}$ Nearly half of all black women over the age of 60 have hypertension. ${ }^{28}$ Black women have a 40 percent higher stroke rate than do white women. ${ }^{29}$ Twice as many black women as white die from strokes. ${ }^{30}$ The incidence rate of uterine cancer for black women is twice that for white women. ${ }^{31}$ Black women also have a higher mortality rate for

22. See generally Robert D. Bullard, Dumping in Dixie: Race, Class and ENvironMENTAL QUALITY (1990). at $\mathrm{D} 3$.

23. Agnes Palazzetti, PCB Findings Cause Concern for Mohawks, Buffalo News, Oct. 17, 1989,

24. Zambrana, supra note 8, at 142 . "[P]oor and racial/ethnic women are most likely to be heads of households, to have larger families, to bear the heaviest burden of caring for the health and well-being of all family members, to be in the poorest health themselves, to experience the greatest psychologically induced symptoms or illnesses, and to be at highest medical risk, particularly during pregnancy and childbirth." Id. at 148.

25. Taunya Lovell Banks, Women and AIDS-Racism, Sexism, and Classism, 17 N.Y.U. REv. L. \& Soc. Change 351, 351 (1990). But see id. at 354-55 (suggesting that the extent of AIDS among white women might be underreported as they are more likely than women of color to be treated in private facilities which have a reputation for underreporting stigmatizing health conditions, especially those involving sexually transmitted diseases).

26. Constance L. Hays, A Sermon on AIDS Where It's Rife, in Harlem, N.Y. Times, Sept. 24, 1990, at B5; see also, Bureau of Communicable Disease CONTROL, New York STATE DEP'T of Health, AIDS SuRveillance MoNTHLy UpDate, 13 (Aug. 1990).

27. Henry L. Davis, Young Adults Avoid Learning About AIDS, Buffalo News, Aug. 9, 1990, at A1.

These medical problems do not exist separate and distinct one from the other. The young woman with AIDS might be pregnant and looking for an abortion. Unfortunately, some health care providers are now refusing to perform abortions on women with AIDS, for fear of contracting the disease. Clinics Often Reject Patients with the AIDS Virus, N.Y. Times, Oct. 23, 1990, at A1. Thus one health problem exacerbates and exaggerates the other.

28. Nancy Cope \& Howard R. Hall, The Health Status of Black Women in the U.S.: Implications for Health Psychology and Behavioral Medicine, SAGE, Fall 1985, at 20, 21.

29. Jean Carper, Stroke Rates Puzzling, Buffalo News, Sept. 25, 1990, at C1.

30. Cope \& Hall, supra note 28 , at 20.

31. Id. 
breast cancer than do white women. ${ }^{32}$ The death rate for black women with diabetes is twice that of white women. ${ }^{33}$ Black women are three times more likely to die while pregnant than are white women. ${ }^{34}$

Alcoholism is also a serious problem for women of color. It is an increasing problem for Indian women on reservations. ${ }^{35}$ It is also a problem for young Latinas as they become acculturated to American patterns of behavior. ${ }^{36}$ Studies have shown that black women are more at risk for developing alcoholism than are black men. ${ }^{37}$ These women are all likely to suffer from alcohol-related diseases and conditions, including cardiac arrythmia, esophagitis, gastritis, pancreatitis, fatty liver, cirrhosis, recurrent diarrhea, and accidental deaths. ${ }^{38}$

Respiratory disease is a serious problem in all Latino communities. If one compares all Latina groups, black women and white women, Puerto Rican women have the highest rate of death due to pneumonia and influenza. ${ }^{39}$ Chinese-American and Latina women face a greater risk of developing diabetes during pregnancy than do comparable black or white women. ${ }^{40}$ Lupus, that mysterious disease of the autoimmune system, affects one in every 750 women to varying degrees. However, it disproportionately afflicts women of color. One in every 500 Latinas and one in every 245 black women suffer from this disease. ${ }^{41}$

AIDS, hypertension, cancer, alcoholism, respiratory disease, diabetes, lupus: This is a litany of deadly names and chilling numbers.

\section{RESEARCH ON THE HEALTH OF WOMEN OF COLOR}

There is not much medical or social science research on the health issues of women of color. Given our disadvantaged status it is not surprising that women of color are a low research priority. ${ }^{42}$ Looking separately at research issues for women in general as well as for people of color provides insight into the contours of this problem.

First, with respect to research on all women, the public is just beginning to realize how little has been done. Too often medical research has focused on the health issues of men; researchers have used only men in clinical trials. For example, recent scientific evidence suggests that biological differ-

32. Id.

33. Id.

34. Id.

35. Michael Dorris, The Broken Cord 87-91, 161, 165 (1989).

36. Kyriakos S. Markides, Neal Krause \& Carlos F. Mendes de Leon, Acculturation and Alcohol Consumption among Mexican Americans: A Three-Generation Study, 78 AM. J. PUB. Health 1178, 1181 (1988).

37. Cope \& Hall, supra note 28, at 22.

38. $I d$.

39. Ira Rosenwaike, Mortality Differentials Among Persons Born in Cuba, Mexico, and Puerto Rico Residing in the United States, 1979-1981, 77 AM. J. Pub. Health 603, 605 (1988).

40. Warren E. Leary, Uneasy Doctors Add Race-Consciousness to Diagnostic Tools, N.Y. Times, Sept. 25, 1990, at C1.

41. Id. at $\mathrm{C} 10$.

42. Zambrana, supra note 8 , at $137-38$. 
ences between the sexes may mean that women develop heart disease differently than men. These findings question many of the common theories on heart disease that were based on research performed on middle-aged men. ${ }^{43}$ In response to pressure from the Congressional Caucus for Women's Issues, the National Institute of Health (NIH) recently created an Office of Research on Women's Health. Its task is to ensure not only that research conducted and supported by NIH addresses issues affecting women's health, but also that there is appropriate participation by women in clinical trials. ${ }^{44}$ The NIH has issued guidelines on research proposals to control this bias. ${ }^{45}$ This is an important first step. Perhaps these new studies on women will shed some light on the health of women of color.

Second, there has been a similar lack of specificity with respect to research on the health of people of color. Researchers have ignored communities of color through a general failure to address the variables of race and ethnicity. ${ }^{46}$ There is some indication that researchers and doctors are now beginning to give more consideration to the racial/ethnic background of their patients when diagnosing and treating illness. One example involves sickle-cell disease, a hereditary blood disease that primarily affects people of African descent. Researchers have discovered that when doctors give blood transfusions to patients with this disease, there are less medical complications if blood from black donors is used. ${ }^{47}$ Another research weakness has been the failure to address heterogeneity within racial and ethnic groups. Some researchers are beginning to look more closely at the geographic location and socioeconomic status of subgroups within racial groups. ${ }^{48}$ Some scientists as well are beginning to address the subtle nature of the social constructs of "race" and "national origin." For example, one scientist studied the relationship between skin pigmentation and high blood pressure among African-Americans. ${ }^{49}$ Thus, by analyzing the social construct, "African-American race," and by isolating one genetic subtlety, "skin pigmentation," the researcher was able to provide a more helpful analysis of the

43. Gina Kolata, The New Mystery of the Female Heart, N.Y. Times, Nov. 17, 1987, at C3.

44. Research-For and By Men: Medical Studies Ignore Half the Population, Buffalo News, Sept. 24, 1990, at B2; see U.S. Dep't of Health and Human Servs., Press Release (Sept. 10, 1990) (on file with the Stanford Law Review); see also Congressional Caucus for Women's Issues, Congresswomen Escalate Efforts on Women's Health, Press Release (Sept. 7, 1990) (on file with the Stanford Law Review).

The Co-Chairs of the Congressional Caucus for Women's Issues introduced the Women's Health Equity Act in February 1991. One bill in this legislation, the Women's Health Research Act (H.R. 1263), would make permanent the Office of Research on Women's Health which NIH created in 1990. See Congressional Caucus for Women's Issues, The Women's Health Equity ACT OF 1991 (Mar. 4, 1991) (on file with the Stanford Law Review).

45. Drug abuse and Mental Health Admin., Nat'l Insts. of Health \& Alcohol, NIH/ADAMHA Policy CONCERNING INCLUSION OF WOMEN IN STUdY Populations, NIH GUIDE, Aug. 24, 1990, at 18.

46. Zambrana, supra note 8, at 150-51.

47. Leary, supra note 40 , at C10.

48. Zambrana, supra note 8 , at 151 .

49. Michael J. Klag, Paul K. Whelton, Josef Coresh, Clarence E. Grim \& Lewis H. Kuller, The Association of Skin Color With Blood Pressure in US Blacks With Low Socioeconomic Status, 265 J. A.M.A. 599 (1991). 
causes of hypertension within the black community. ${ }^{50}$

Unfortunately, however, a decision to study women does not necessarily mean that different kinds of women will be seen and studied; and a decision to study genetic and cultural factors does not mean that the effects will be analyzed with reference to sex. Two researchers who studied the health status of black women have noted that even when studies look at race as well as gender, they generally look at either race or gender, thus ignoring the existence and health concerns of women of color. ${ }^{51} \mathrm{~A}$ lot more research is needed-research on women, on people of color, and on women of color.

As researchers start to look at genetic inheritance and cultural factors along with sex difference, we might finally see research which looks at issues unique to certain women of color groups. Thus, we might learn, for example, why the infant mortality rate for babies born to Mexican-American mothers is lower than that of black mothers, despite the fact that both groups of women tend to look similar with respect to socioeconomic status and prenatal care. ${ }^{52}$ We might also learn why their infant mortality rate is even lower than that of white mothers, who tend to have higher incomes and better prenatal care. 53

\section{CONCEPTUAlizing THE "Woman OF COLOR ISSUE"}

The term "women of color" can be a helpful political tool. It is a phrase which is affirming and generous, a phrase which brings together a powerful coalition of women. However, there appears to be some uncertainty as to whether there is such a thing as a "true" women of color issue because these issues are often subsumed within the issues of others-white women, poor women, men of color. For example, Laurie Nsiah-Jefferson has discussed reproductive issues for poor women and women of color, ${ }^{54}$ thus collapsing women of color issues and poor women's issues into one. At other times, researchers combine the problems of women of color with those of the relevant community of color. For example, in a recent talk on the health problem of Latinas, Ruth Zambrana talked about health issues which face the Latino community as a whole. She thus treated together those issues which face men, as well as women, within the Latino community. ${ }^{55}$ Women's issues were thus confounded with Latino issues in general. The varied ways in which women of color issues are presented leads one to ask what precisely are women of color issues. Do such issues exist? Or are women of color issues the same issues as those faced by poor white women? Are they the

50. See, e.g., Robert F. Murray, Jr., Skin Color and Blood Pressure: Genetics or Environment?, 265 J. A.M.A 639 (1991) (concluding on the basis of the Klag study, supra note 49, that socioeconomic environment is crucial factor in elevated blood pressure of darker-skinned individuals).

51. Cope \& Hall, supra note 28 , at 20.

52. Leary, supra note 40 , at $\mathrm{C} 10$.

53. Id.

54. Nsiah-Jefferson, supra note 5, at 15-40.

55. See generally Ruth E. Zambrana, Latino Family Health Issues: Implications for Policy Formulations (paper presented at the Third National Conference on Women of Color and the Law, Stanford Law School, Oct. 6, 1990) (unpublished manuscript on file with the Stanford Law Review). 
same issues faced by men of color? Are they somehow different? Does it matter how these questions are answered? And if it does, why does it matter? It is these questions that I will address in the context of health issues of women of color.

The initial answer is that women of color bear all the burdens of white women as well as all those of men of color. Many Latina and Asian-American women must deal with language and immigration problems, as do many Latina and Asian-American men. They must also deal with problems related to pregnancy and childbirth, as do all women. The next step is to look at what happens when the issues of people of color and women intersect. Take, for example, the case of a Latina who is pregnant. Her relative ability or inability to get good prenatal care may well be influenced by her status as an undocumented worker or by her lack of fluency with English. ${ }^{56}$ It is at the confluence of these two problems-difficulties because she is a woman, difficulties because she is part of the Latino community, that one finds a women of color issue. 57

One way to locate and identify these issues, then, is to use as a point of entry an issue which has already been identified as a "woman's issue" or as an issue for people of color and to then explore that issue with an eye towards locating this point of intersection. This intersection can be identified when one sees that there is a greater impact on women of color, or that women of color are treated differently with respect to this issue. Thus, when I find that greater impact or differential treatment, I will have located a women of color issue. ${ }^{58}$ Using the health context, I will give an example for each segment of this four-part framework.

I will start with women's health issues and look for differential impact. Using this definition, abortion is a prime women of color issue, for statistics show that a disproportionate percentage of American women seeking abortions are women of color. The abortion rates for black women are higher than the abortion rates for white women. ${ }^{59}$ They obtain 31.4 percent of all

56. See Zambrana, supra note 8, at 149-50 (language barrier limits access to health education and health care system for Latinas).

57. For further discussion of philosophical and legal issues that arise at the intersection of race or ethnicity and gender, see Elizabeth V. Spelman, Inessential Woman: Problems of ExCLUSION IN Feminist Thought (1988); Kimberle Crenshaw, Demarginalizing the Intersection of Race and Sex: A Black Feminist Critique of Antidiscrimination Doctrine, Feminist Theory and Antiracist Politics, 1989 U. CHI. LEgal F. 139; Judy Trent Ellis, Sexual Harassment and Race: A Legal Analysis of Discrimination, $8 \mathrm{~J}$. LEGIS. 30 (1981); Angela P. Harris, Race and Essentialism in Feminist Legal Theory, 42 STAN. L. REv. 581 (1990); Judy Scales-Trent, Black Women and the Constitution: Finding Our Place, Asserting Our Rights, 24 HARv. C.R.-C.L. L. REv. 9 (1989).

58. These two concepts, "greater impact" and "differential treatment," are, of course, very closely related. In many instances, the greater impact is caused by differential treatment. I use the concepts separately here, however, in order to provide two patterns to use in the search for women of color issues.

59. R. Petchesky, supra note 9, at 152. At all ages over twenty, the ratios of abortion per 1,000 live births for black women are higher than the ratio for white women. However, the ratio for white teenagers is higher than the ratio for black teenagers. Id. 
legal abortions in the country. ${ }^{60}$ The strong statistical imbalance makes abortion a women of color issue. The numbers show us the impact. Similar health issues which are primarily women's issues, but which have a greater impact on women of color, are coerced sterilization, ${ }^{61}$ and research and treatment with respect to the disease Lupus, which attacks women of color in disproportionate numbers. ${ }^{62}$

The prosecution of pregnant black and Latina women for fetal drug abuse is a good example of a woman's issue which becomes a women of color issue because of the way women of color are treated. Research has shown that although white women are more likely to be drug abusers than are black women, black women are ten times more likely than white women to be tested for drugs and reported to the authorities for drug abuse. ${ }^{63}$ It is the differential treatment of women of color for the same issue which white women face, which makes this a paradigmatic issue for women of color.

The second way to get at women of color issues is to use the group of color as a point of entry for the exploration. One then looks for an issue with a greater impact on the women of that group, or for ways in which the women in the group are treated differently. First, in thinking about differential impact, consider sickle-cell anemia, a blood disease which disproportionately affects African-Americans. ${ }^{64}$ And then think about a black woman with sickle-cell anemia who wants to get pregnant, or who finds herself pregnant and wants an abortion, or who simply wants counseling about the risk that she might run if she decides to get pregnant. Because of the pregnancy risk, will the mortality statistics for sickle-cell anemia show a greater impact on black women? Think also about the lactose intolerance of many AfricanAmericans. For black women, this will become an important factor in their poor nutrition. And this, along with other factors, creates a situation where black women are four times more likely to die in childbirth than are white women. ${ }^{65}$ Will this statistical disparity also show up in data on illness and death within the African-American community?66

With respect to differential treatment of women of color within the perspective of problems facing communities of color, I would start, for example, with the lack of enforcement of basic labor laws and its effect on the health of Latino families. ${ }^{67}$ To find the issue for Latinas, I would ask whether these labor laws operate in different ways based on the kind of job one holds. For

60. Stanley K. Henshaw \& Jane Silverman, The Characteristics and Prior Contraceptive Use of U.S. Abortion Patients, 20 Fam. Plan. PeRSP. 158, 162 (1988).

61. Banks, supra note 25, at 361-63.

62. Leary, supra note 40 , at $\mathrm{C} 10$. B2.

63. See Dan Holly, Study: Race Affects Drug-Abuse Testing, Miami Herald, Sept. 19, 1989, at

64. See text accompanying note 47 supra.

65. Ruth H. Gordon-Bradshaw, A Social Essay on Special Issues Facing Poor Women of Color, 12 WOMEN \& HeALTH, Fall \& Winter, 1987, at 243, 256.

66. See, e.g., Zambrana, supra note 8, at 142 (life expectancy of women of color five to seven years lower than that of white women).

67. See, e.g., Zambrana, supra note 55, at 13-14 (many Latino men and women participate in a secondary labor market and do not receive the benefit of labor laws). 
example, to the extent that Latinas (and not Latinos) are clustered in domestic work, ${ }^{68}$ does the isolation of this work and the invisibility of these workers create a different kind of problem for them? ${ }^{69}$ And what about the availability of bilingual health care providers for the Latino community? ${ }^{70}$ Will the bilingual women within that community face different kinds of discrimination than the men with respect to admission to medical schools? selection for residence? hire?

I have suggested that a women of color issue can be located by looking at a woman's issue, or at an Asian or black or Indian or Latino issue, and by pushing further into that issue to locate the point where women of color look different-either because they suffer disproportionately or because they suffer differently. But what of the class issues? Does this analytic framework take into account the fact that women of color are generally poor? We must ask if the issues they face are really just related to poverty and not uniquely to the intersection of sex and race or ethnicity.

There is no doubt that the question of class is present in the framework presented above, for class is implicated in the stereotypes associated with race, ethnicity, and sex categories. As a result, there are very few wealthy women of color. We are stereotyped and tracked into certain jobs, housing, and education because of our race, ethnicity, and/or sex..$^{71}$ And because this stereotyping and tracking makes us poor, we are then treated badly because we are poor. Women of color have all of the issues of men of color and all of the issues of white women, but our issues play out differently because of the stereotypes, hence the tracking and the controls are different. Race, ethnicity, and gender intersect, and class is implicated in each element of this intersection. ${ }^{72}$

The problem of the disproportionate number of pregnant black women drug addicts prosecuted for fetal abuse provides a good example of the interlocking nature of race/ethnicity and sex and class. ${ }^{73}$ Let us think about one of these women. Because she is black and a woman, and because she has been locked out of certain education and jobs because of her sex and race, she will likely be poor. ${ }^{74}$ Because she is poor, she will go to a public hospital

68. See PAY EQurTY, supra note 3, at 29 (domestic work has high concentration of Latina workers).

69. For example, a study of Mexicana domestic workers in El Paso revealed that these women face problems of unpaid minimum wage, sexual harassment, and assault. Vicki L. Ruiz, By the Day or the Week: Mexicana Domestic Workers in El Paso, in WOMEN ON THE U.S.-Mexico BoRder: Responses to Change 61-74 (V. Ruiz \& S. Tiano eds. 1987).

70. See, e.g., Zambrana, supra note 55, at 14-15 (the lack of health care professionals who are bilingual and bicultural contributes to the inaccessibility of primary health care for Latinos).

71. See generally Teresa L. Amott \& Julie A. Matthaei, Race, Gender and Work: A MULTICULTURAL ECONOMIC HISTORY OF WOMEN IN THE UNITED STATES (1991).

72. Id. at 13 ("Race-ethnicity, gender and class are interconnected, interdetermining historical processes, rather than separate systems.").

73. See text accompanying note 63 supra.

74. See, e.g., T. AMOTT \& J. MATTHAEI, supra note 71, at 183-84 ("A significant share (about one-fifth) of all Blacks is caught in the long-term cycle of poverty, segregated into inferior housing, schools, and jobs. ... Single-mother families represent three-quarters of poor Black families."). 
for medical care, where she will be subject to state scrutiny. ${ }^{75}$ Because she is a woman, she may depend on a state hospital for reproductive services. And because she is black, she will be scrutinized by hospital staff more closely than will be the white women who are there. Because she is black, she "looks like" a drug user to them. ${ }^{76}$ It is the intersection of these three strands-race, sex, poverty-that creates this particular problem for black women.

\section{CONCLUSION}

It is important to go through this analysis in order to recognize that there are indeed very important women of color issues that confront us today. And it is important to assess how these issues are put together, important to understand the elements of our oppression, in order to understand how best to confront them. It is immediately evident that the only way that women of color issues will be addressed successfully is through coalition work with women's groups and groups of people of color, for we have staggering problems and meager resources.

It is also immediately clear that our health needs must be defined very broadly. They must also be redefined as civil rights, in order to reinforce the sense of urgency and entitlement. Thus, when activists and scholars write about reproductive "rights" for women of color, and when they then define these rights broadly to include a healthy workplace, health education, access to good health care, and whatever it takes to give birth to a healthy child, ${ }^{77}$ they are showing us the path we must take. For the problems of women of color extend far beyond health. The problems in our communities extend far beyond health. And we will not get well until our communities get well.

75. Cf. Banks, supra note 25 , at 355 n. 15 (black and Latina women, forced to rely on public hospitals and clinics, more likely to be identified and reported as infected with HIV than women using private facilities). women).

76. Holly, supra note 63 (doctors less likely to suspect drug abuse by white middle-class

77. See, e.g., Charlotte Rutherford, Reproductive Freedoms and African-American Women (unpublished manuscript) (on file with the Stanford Law Review). 